\section{Pacific Northwest}

National Laboratory

Operated by Battelle for the

U.S. Department of Energy

\title{
Single-Step Process to Treat the High Chloride Pu Inventory at the Plutonium Finishing Plant (PFP)
}

Robert Leugemors

Paul MacFarlan

Stanley Jones
Cal Delegard

Dale Wallace

March 2002

Pacific Northwest National Laboratory is operated by Battelle

for the U.S. Department of Energy

under Contract DE-AC06-76RL01830

This work is funded by the office of Science and Technology, within the Department of Energy's Office of Environmental Management, under the Nuclear Materials Focus Area. 


\section{DISCLAIMER}

This report was prepared as an account of work sponsored by an agency of the United States Government. Neither the United States Government nor any agency thereof, nor Battelle Memorial Institute, nor any of their employees, makes any warranty, expressed or implied, or assumes any legal liability or responsibility for the accuracy, completeness, or usefulness of any information, apparatus, product, or process disclosed, or represents that its use would not infringe privately owned rights. Reference herein to any specific commercial product, process, or service by trade name, trademark, manufacturer, or otherwise does not necessarily constitute or imply its endorsement, recommendation, or favoring by the United States Government or any agency thereof, or Battelle Memorial Institute. The views and opinions of authors expressed herein do not necessarily state or reflect those of the United States Government or any agency thereof.

\section{$\underline{\text { Acknowledgments }}$}

This work was prepared with the support of the following contributors:

$\begin{array}{ll}\text { Headquarters: } & \begin{array}{l}\text { Office of Science and Technology } \\ \text { Stanley Wolf, EM-54 }\end{array} \\ \text { Focus Area/Program: } & \begin{array}{l}\text { Nuclear Materials Focus Area } \\ \text { Gary Roberson, DOE-AL }\end{array} \\ \text { Operations Office: } & \begin{array}{l}\text { Richland Operations Office } \\ \text { Environmental Management Technology } \\ \text { Division } \\ \text { Marcus J. Glasper, Technical Program Officer }\end{array} \\ & \begin{array}{l}\text { Pacific Northwest National Laboratory } \\ \text { Environmental Science and Technology } \\ \text { Environmental Technology Directorate } \\ \text { John P. LaFemina, Director }\end{array}\end{array}$

This document was printed on recycled paper. 
PNNL-13839

\title{
Single-Step Process to Treat the High Chloride $\mathrm{Pu}$ Inventory at the Plutonium Finishing Plant (PFP)
}

\author{
Robert Leugemors Cal Delegard \\ Stanley Jones Dale Wallace \\ Paul MacFarlan
}

March 2002

Pacific Northwest National Laboratory is operated by Battelle

for the U.S. Department of Energy under Contract DE-AC06-76RL01830

Pacific Northwest National Laboratory

Richland, Washington 99352 


\section{Executive Summary}

\section{Problem to be Investigated}

The Plutonium Finishing Plant (PFP), operated by Fluor Hanford, has up to 1000 plutonium oxide bearing items in their inventory containing high concentrations of chloride salts. These items must be stabilized at $>950^{\circ} \mathrm{C}$ for at least 2 hours to meet DOE-STD-3013 requirements (DOE 2000). The presence of chlorides is problematic, because some of these salts are volatile at $>800^{\circ} \mathrm{C}$ and very corrosive to the furnace and off-gas system. Early testing at PFP indicated this corrosive effect as well as significant salt deposits in the off-gas line.

After stabilization, a sample of the material must undergo a Loss-on-Ignition (LOI) test to demonstrate that the stabilized material has $<0.5 \%$ moisture to satisfy DOE-STD-3013 requirements (DOE 2000). This moisture content is determined by heating a sample of the stabilized material to $1000^{\circ} \mathrm{C}$ to measure the weight loss. All weight loss is assumed to be moisture (water). Consequently, any salt remaining after stabilization will volatilize to some extent during the LOI testing. This could cause the sample to fail the LOI test and require additional stabilization processing for the failed material even though moisture content is less than $0.5 \%$.

Pacific Northwest National Laboratory (PNNL) identified a process whereby the volatile salts potentially could be separated from the plutonium oxide. This process would also mitigate salt corrosion effects in the furnace and off-gas system. In July 2001, the Nuclear Material Focus Area requested PNNL to design, build, and test a simple proof-of-principle system.

\section{Testing Approach}

PNNL designed a system to contain and control the volatile salt vapors by providing a boat/lid combination maintained at slight vacuum relative to the muffle furnace. The vacuum provides airflow from the muffle furnace into a downstream off-gas and cold quench system. This flow prevents salt vapors from contacting the muffle furnace. The off-gas line is heated and insulated to the quench chamber where the heated salt vapors are contacted with a large quantity of room temperature air. This rapid cooling precipitates the salt vapors resulting in crystallized salt particles that deposit on the system walls or flow to the filter.

If successful, this system would provide a single-step process that would remove volatile salts from $\mathrm{Pu}$ oxides and isolate corrosive vapors from sensitive furnace components. If the Pu oxides containing chloride salts could be processed in a single thermal stabilization step, significant dose, as well as budget and schedule could be saved. 


\section{Objectives}

Four key issues required testing:

1. confirm that the system could contain the corrosive chloride salts to prevent damage to the muffle furnace

2. confirm that the salts would not deposit (and plug) in the off-gas line

3. determine the salt deposition location and magnitude

4. determine the salt removal rate.

In lieu of paper evaluations, modeling, and analysis, it was determined that a proof-of-principle system could be built that would provide actual data to evaluate potential application of this system at the PFP. Within 6 months the system was designed, parts procured, the test system installed, and 2 tests performed.

\section{Results}

Two tests were run and the following are key observations:

- the muffle furnace was protected from corrosive gases

- the off-gas piping had no visible salt buildup or corrosion

- the salt deposition was limited to areas where it was expected

- the ceramic boat and lid had inadequate thermal conductivity

- the Haynes HR-160 boat and lid showed significant corrosion. Post-weld annealing may improve the corrosion resistance or the boat and lid could be regularly replaced if necessary.

- the salt removal rate appears to be too slow to enable complete removal of the chloride salts under process conditions.

\section{Recommendations}

The system contained and controlled the volatile salts but volatilization rates were too slow to achieve timely separation. The only path for successful implementation of this system requires process qualification. If the process could be successfully qualified, it would offer significant improvement over the washing technology. At this point, this represents the best opportunity, known at this time, for singlestep processing. 


\section{Contents}

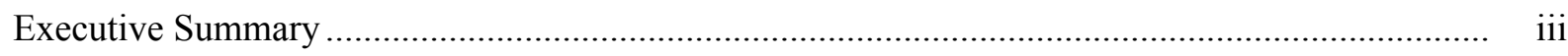

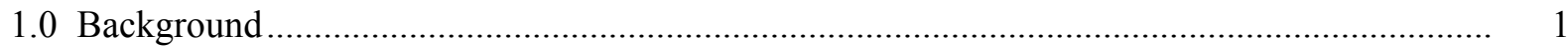

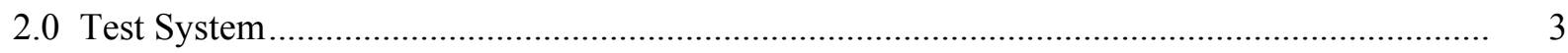

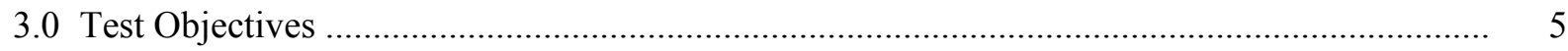

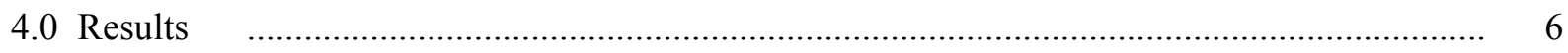

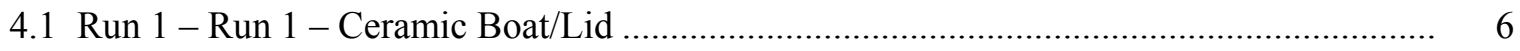

4.2 Run 2 - Run 2 - Haynes HR-160 Boat/Lid ............................................................... 6

4.2.1 Path Forward for Plutonium Finishing Plant Application...................................... 8

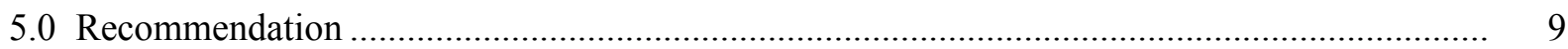

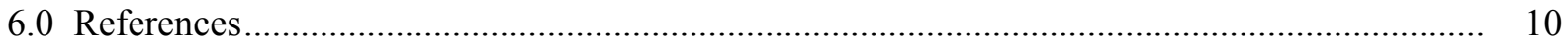




\subsection{Background}

The inventory of high chloride-salt-bearing Pu oxide items at PFP is estimated to be up to 1000 items. These items must be stabilized in an oxidizing atmosphere for at least 2 hours at a temperature of at least $950^{\circ} \mathrm{C}$ to undergo thermal stabilization processing to meet DOE-STD-3013 criteria (DOE 2000). This ensures that the $\mathrm{Pu}$ is oxidized, but it is also intended to ensure that the remaining moisture content is less than $0.5 \%$ of the total material weight (DOE-STD-3013). The moisture content is determined by performing an LOI test from a sample of the stabilized material. This involves heating the sample to $1000^{\circ} \mathrm{C}$ for 1 hour and then measuring the weight loss. If salt remains in the material after stabilization, this salt could be partially removed during LOI testing and could cause failure for that test. This would be unacceptable since additional stabilization would then be required. It is important to note that the actual requirement pertains only to residual moisture (water) and not to salt content. There are no DOE-STD-3013 requirements for salt, but since weight loss is assumed to be all water (moisture), the partial removal of salt during LOI testing would be interpreted as moisture. There is another alternative identified in DOE-STD-3013 that involves process qualification. Specifically, DOE-STD-3013 Section 6.1.2.2 states

"Process Qualification: Materials that have been stabilized and packaged using a "qualified process" shall be subject to reduced testing requirements. A qualified process is one that has demonstrated, to the satisfaction of an independent review group as indicated in the Foreword, Item 5, to consistently meet the requirements of Criterion 6.1.2.3. Once this process has been qualified, material testing, as described in 6.1.2.2.1, is required only to the extent necessary to show continued process control." Foreword, Item 5 states that evaluations or determinations should be submitted to the Nuclear Materials Stewardship Project Office (NMSPO), Albuquerque Operations Office, with specific items identified. Section 6.1.2.3 states "Stabilization Acceptance Criterion: The moisture content (weight loss, if using the LOI method) of Oxide to be packaged in any type of sealed container shall be less than $0.5 \mathrm{wt} \%$ at the time of packaging."

A second, and perhaps more limiting aspect of the volatile salt in the material is that at stabilization temperature, it is recognized that significant salt corrosion damage to the muffle furnace would occur unless mitigated. The most straightforward and dependable method to mitigate the salt involves water washing to dissolve and remove the salts, drying the washed solids on a hot plate, followed by thermal stabilization in the muffle furnace. This process will adequately treat the high chloride salt $\mathrm{Pu}$ and provide high confidence for achieving DOE-STD-3013 requirements related to residual moisture content. However, it requires multiple handling, transfer, and process steps that are operator and dose (ALARA) intensive. This is significant because qualified operators are a limiting resource and consequently this represents a schedule limiting aspect for PFP Pu stabilization.

PNNL was asked to evaluate and identify improved process options for the high chloride salt $\mathrm{Pu}$ oxide. Several options were reviewed including washing, distillation, and pyrolysis for application to PFP. Distillation of the volatile salts appeared to have the most promise of reducing cost and schedule for processing. PNNL proposed an engineered solution to exploit the volatile nature of the salts to remove 
them with a system designed to prevent muffle furnace corrosion and off-gas plugging. It should be noted there are chloride salts $\left(\mathrm{CaCl}_{2}\right)$ that are not volatile at stabilization temperature and subsequently will not be removed during stabilization. These salts are problematic since they absorb moisture at low temperatures. To minimize LOI testing concerns, the system at PFP would require a dry atmosphere for processing and storage downstream of the thermal stabilization step. 


\subsection{Test System}

To minimize the cost, PNNL developed a simple proof-of-principle test system to determine if this single-step process would remove volatile chloride salts from $\mathrm{Pu}$ oxide and isolate the corrosive salts from the sensitive furnace components. The test system drawing and system photographs (Attachments 1 and 2) aid understanding of the following process description.

The basic concept is to exploit the salt volatility to separate the salts from the nonvolatile $\mathrm{PuO}_{2}$. For this test, $\mathrm{CeO}_{2}$ (cerium oxide) was used as a surrogate material for $\mathrm{PuO}_{2}$. The chloride salts and the cerium oxide mixtures were heated to $1000^{\circ} \mathrm{C}$ in a muffle furnace (Thermolyne Type FA1600 Furnace) similar to the one used at PFP. At this temperature, $\mathrm{NaCl}, \mathrm{KCl}$, and $\mathrm{MgCl}_{2}$, which exist in some of the PFP items, are liquid and have vapor pressures between about 8 to $23 \mathrm{~mm} \mathrm{Hg}$. In contrast, the vapor pressure of $\mathrm{CaCl}_{2}$ is $\sim 0.04 \mathrm{~mm} \mathrm{Hg}$. Though the vapor pressures of $\mathrm{NaCl}, \mathrm{KCl}$, and $\mathrm{MgCl}_{2}$ are low, evaporation will occur at stabilization temperatures. Figure 1 presents salt vapor pressure data (Stull 1947; Stull Prophet 1971; Novikov and Gavryuchenkov 1964)

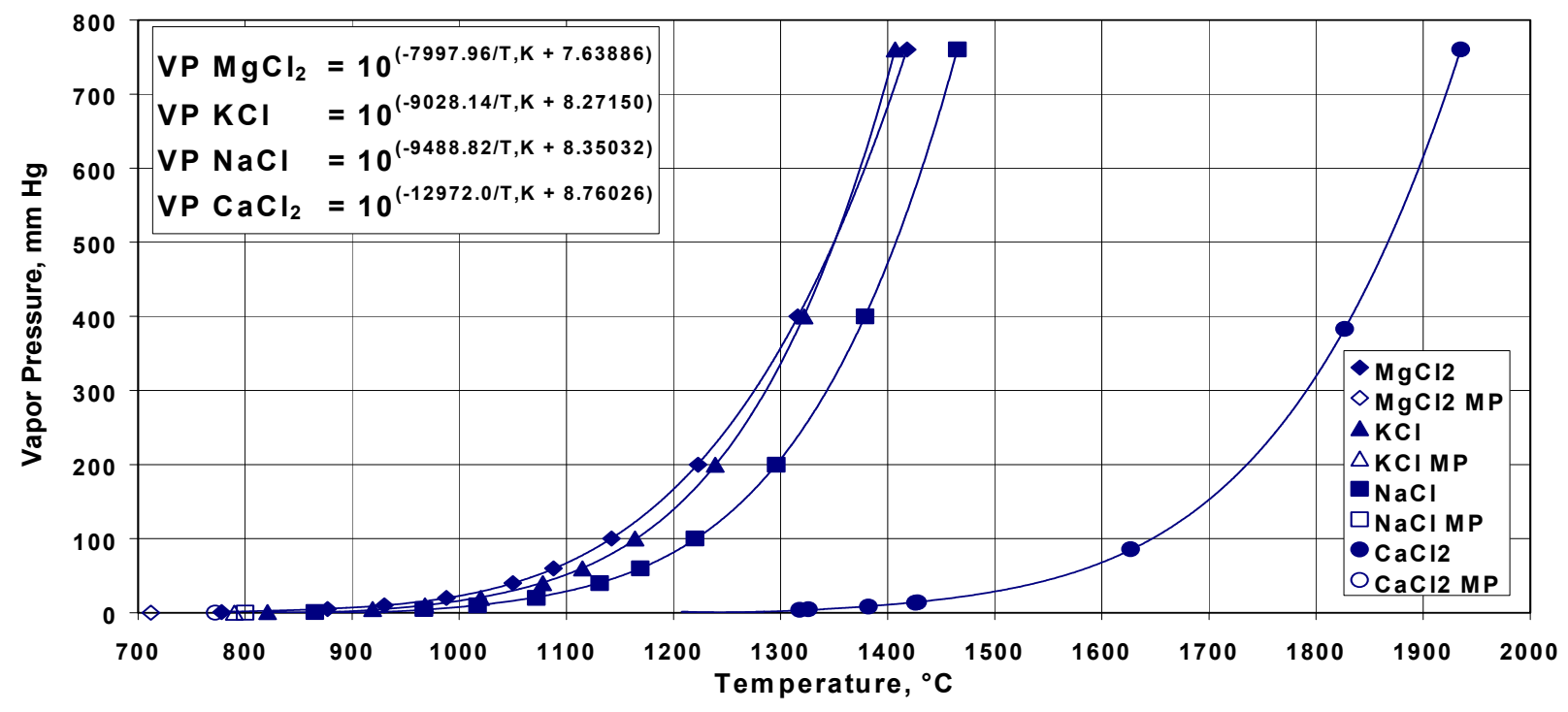

Figure 1. Salt Vapor Pressure as a Function of Temperature

As air flows over the mixture, salt evaporates. The rate of salt evaporation is a function of several factors including vapor pressure, heat transfer rate, latent heat of vaporization, and the mass transfer rate through the material. Due to the complex nature of removal, the rate is most cost-effectively determined by experiment.

The vapor-containing salt is drawn from the boat with a loose fitting lid through the off-gas pipe into an air quench chamber. The off-gas pipe and one end of the quench chamber were heated (using Watlow Fiber Heating Units) to greater than $800^{\circ} \mathrm{C}$ to prevent the salt from solidifying in the off-gas line. This was considered an important design feature to avoid plugging the off-gas line. At the other end of the 
quench chamber, a flow ( $\sim 10$ times the volume of muffle furnace flow) of room temperature air is used to quench the muffle furnace vapor containing the volatile salts to a gas temperature below $200^{\circ} \mathrm{C}$. The immediate decrease of the furnace off-gas temperature precipitates the volatile salts. The resulting aerosol is passed through a $1-\mu \mathrm{m}$ filter and then through the air ejectors (vacuum source) and into a drum filled with water to capture the remaining salts and aerosols.

The off-gas pipe and the quench chamber were made from a special Haynes Metal Alloy HR-160 having claimed corrosion resistance in chloride salt environments. Two other Haynes coupons (HR-188 and HR-214) were tested for comparison to the HR-160. For the first run, the boat and lid were ceramic and for the second run the boat and lid were made of Haynes HR-160. In both runs a hole was made in the lid to allow the installation of the boat/lid combination onto the off-gas pipe. Also, the lid and vent connections to the boat were loose to allow gas flow from the furnace chamber into the boat interior. The remaining parts of the system were stainless or carbon steel since the temperatures involved were relatively low. 


\subsection{Test Objectives}

The most significant items evaluated during testing included:

- confirm that the system, as designed, would contain and capture the corrosive salts to prevent damage to the muffle furnace

- confirm that the materials of construction would be adequate for this application

- locate and evaluate the magnitude of salt deposition within the quench chamber

- determine the rate of salt removal and change in salt concentration of the simulant salt-bearing oxide material. 


\subsection{Results}

\subsection{Run 1 - Ceramic Boat/Lid}

During the first run, the boat and lid were ceramic (composition $\sim 87 \% \mathrm{SiO}_{2}$ and $\sim 10 \% \mathrm{Al}_{2} \mathrm{O}_{3}$ ). The simulant mixture was made with 5 weight $\% \mathrm{NaCl}, 5$ weight $\% \mathrm{KCl}$, and 90 weight $\%$ cerium oxide. All chemicals used for both runs were obtained from Alpha Aeser as follows: $\mathrm{NaCl}, \mathrm{ACS}, 99 \%$ minimum assay; $\mathrm{KCl}$, ACS, 99\% minimum assay; and $\mathrm{CeO}_{2}$ REacton, 99.9\% (REO) 5 micron powder. 432.4 grams of this mixture were placed in the boat. The boat/lid combination system was heated in the muffle furnace to $1000^{\circ} \mathrm{C}$ and held for 2 hours (normal time at temperature to satisfy DOE-STD-3013) and then cooled to room temperature. The vendor-supplied muffle furnace controller achieved heat up from room temperature to $1000^{\circ} \mathrm{C}$ in approximately 3 hours. At the end of the run at the operating temperature of $1000^{\circ} \mathrm{C}$, the following parameters were noted: quench air temperature $190^{\circ} \mathrm{C}$, pressure at the inlet to the filter 0.25 inches water column vacuum, the pressure on the outlet from the filter 1.25 inches water column vacuum, air quench flow was 9.6 CFM.

In the post-heat treatment review, it was evident that the cerium oxide salt feed was not heated through. Based on the changed coloration of the material (See Attachment 2 photos) there was a distinctive layer of material at the top of the boat that appeared to have been heated. The remaining portion of the boat did not appear to have been heated. The high temperature airflow evidently contacted and heated the top layer, but the ceramic insulating properties of the boat and lid reduced the radiative heat transfer to the remaining contents. Inspection indicated some cerium oxide and salt downstream in the quench chamber and filter. The cerium is a 5-micron powder that does not volatilize at $1000^{\circ} \mathrm{C}$ but was likely entrained by the airflow. The water in the drum (scrubber) indicated a small electrical conductivity increase due to the salt (cerium oxide is not soluble in water and would not affect the conductivity). The off-gas pipe and quench chamber showed no visible signs of corrosion. The metal coupons however, did show some limited corrosion.

The useful data obtained from Run 1 was limited because of the short run time and the failure to achieve calcination temperature due to the poor heat transfer into the boat and lid. It did, however, demonstrate containment of the chloride salts and limiting of corrosion in the off-gas and quench system. Ceramic boats could be used but the slow heat transfer rate appears to be prohibitive for time-efficient processing.

\subsection{Run 2 - Haynes HR-160 Boat/Lid}

To maximize the heat transfer through the boat/lid combination, the boat and lid were made from the Haynes Alloy HR-160. A simulant mixture of $15 \% \mathrm{NaCl}, 15 \% \mathrm{KCl}$, and $70 \%$ cerium oxide was made from the same source materials as used in Run 1. The boat was filled with 692 grams of this mixture.

The system was heated and run at temperature for 6 hours. At the end of the run at operating temperature of $1000^{\circ} \mathrm{C}$, the following parameters were noted: quench air temperature, $129^{\circ} \mathrm{C}$; pressure at the inlet to the filter, 0.25 inches water column vacuum; the pressure on the outlet from the filter, 2.9 
inches water column vacuum; air quench flow of 7.8 CFM. It is interesting to note that the increase in quench solution conductivity began when the muffle furnace temperature reached $800^{\circ} \mathrm{C}$, which is consistent with the melting point range of the salts. During this time, the conductivity of the solution increased approximately linearly with time indicating that salt continued to be removed from the boat. In addition, the solution $\mathrm{pH}$ also decreased consistent with the conductivity increase. At the end of the shift, the rate of change in conductivity and $\mathrm{pH}$ were steady so the system was shut down with plans to heat up again after $\mathrm{pH}$ adjustment was made to correct the $\mathrm{pH}$ to neutral. After $\mathrm{pH}$ adjustment, the system was again heated to temperature and salt came off for about 1 hour and then the conductivity of the drum held constant. As a final check, the temperature of the furnace was increased to $1050^{\circ} \mathrm{C}$ and held for an additional 45 minutes to check for additional salt removal, but no perceptible increase in conductivity was noted. The system was shut down and final samples taken from the boat contents.

The inspection of the off-gas piping and quench chamber indicated no visual corrosion, but the boat and lid had substantial corrosion. Based on discussion with scientists and engineers at PFP, this should have been expected due to the welding of the boat versus the annealed off-gas pipe. The other metal coupons had poor corrosion resistance.

Although the boat/lid combination corroded, these components could be changed on a regular basis. In contrast, it was fortunate that the off-gas system components did not exhibit visible corrosion. It would clearly be more difficult to replace the off-gas system in the glovebox environment. The inspection of the remaining mixture indicated a fairly uniform matrix that was hard but brittle and appeared to be porous and was easily ground to a powder. The condition of the entire matrix from the second run was consistent with the top layer from the previous run indicating that the salts had melted and all the material was heated to temperature.

Analytical results of the pre- and post-heat treatment materials were inconclusive to determine the extent of salt removal. The pre-heat treatment samples should have contained $15 \% \mathrm{NaCl}, 15 \% \mathrm{KCl}$, and $70 \%$ cerium oxide but the samples taken from the feed varied widely as did the post-treatment samples. Even after mortar and pestle grinding and remixing, the sample analyses varied widely from expected values. Only the general trend of some salt removal was evident. The potential cause of this variation may be that each component has a different particle size, and an imperfect distribution in the samples could cause significant compositional variation. In addition, the airflow entrained some of the cerium oxide (5- $\mu \mathrm{m}$ particle size), which would tend to reduce the apparent removal percentage of the salts.

The best data demonstrating salt removal were obtained from the drum filled with approximately 40 liters of water intended to capture small salt particles. The water in the drum indicated conductivity increases throughout the test. Attachment 3 shows the two operating days for Run 2. A third graph provides a composite of the 2 days of operation. This composite uses conductivity increases with time from the second day in order allow a continuous single graph to be developed. Based on the conductivity change and the approximate volume of water in the drum, it is estimated that 15 grams of salt were captured in the drum water. Based on the $1-\mu \mathrm{m}$ nominal filter size, the salt that is quenched from the vapor state forms some sub- $\mu \mathrm{m}$ particles. The filter did capture the cerium with a $5-\mu \mathrm{m}$ nominal size. Again, due to the limited number of runs, quantitative understanding of the salt removal rate is not known. It is interesting to note that on the first day of operation, the drum conductivity increased at approximately $110 \mu \mathrm{S} / \mathrm{cm}$ per hour but the next run had less than $20 \mu \mathrm{S} / \mathrm{cm}$ per hour. It is not known if 
the shutdown and cooldown of the system impacted this removal rate or if the reduced rate would have occurred in the next hour in any event. Again, the only objective data are that salt was removed but a significant amount of salt clearly remained in the boat. This limited data is qualitative but strongly implies that $>99.5 \%$ removal of salt in a short operating time frame is unlikely.

\subsubsection{Path Forward for Plutonium Finishing Plant Application}

To successfully pass the LOI test after the 2-hour stabilization, two key goals must be met. First, the volatile salts need to be removed to less than $0.5 \%$ of the total mass. Second, since the nonvolatile salts $\left(\mathrm{CaCl}_{2}\right)$ will capture moisture from humid air, a controlled dry atmosphere must be maintained after thermal stabilization through completion of canning operations. An additional concern was raised that the salts remaining in the boat may corrode the DOE-STD-3013 container. Although there is no requirement in the DOE-STD-3013, Mr. Ted Venetz (Fluor Hanford) noted that the convenience container could be changed to Hasteloy, which is more resistant to room temperature chloride salt corrosion without impacting the DOE-STD-3013 canning operations. The nominal DOE-STD-3013 inner and outer container material is $316 \mathrm{~L} \mathrm{SS}$. Since this process does not appear to completely remove the salts in a time-effective manner, product from this process is unlikely to meet the DOE-STD-3013 for moisture by LOI testing. 


\subsection{Recommendation}

Because the volatile salts are not completely removed during thermal stabilization, process qualification per DOE-STD-3013 provides the best opportunity for the single-step process. In this case, thermal gravimetric analysis-mass spectrometry would be used to demonstrate that the stabilized material meets the $<0.5$-wt $\%$ moisture content requirement. This requires a significant effort and risk since other issues may arise during the qualification process including demonstrating maintenance of a low humidity atmosphere for the stabilized product. Process qualification does, however, represent the most promising means to utilize a single-step process for treating $\mathrm{Pu}$ oxides containing salts.

Future testing to provide additional understanding and information for this system should include

1. LOI testing from a sample of the post-heat treated material. There were some compounds formed by the salts with the corrosion products from the boat. It would be useful to determine the amount of remaining volatile salts. Due to the variability of the materials, replicate tests are suggested.

2. A system test in which the entire prepared sample is used for the run. This will eliminate the uncertainty with the initial feed composition. In addition, it is suggested that the airflow be reduced from 1 SCFM to $\sim 0.25$ SCFM to evaluate potential improvement in radiant heating and reduction in cerium oxide entrainment with consequent decrease in salt removal. It would be useful to run the system continuously to obviate the effect, if any, of shutdown and cooldown on the salt removal rate.

If data from the additional tests described above indicate improved salt removal rates and a low final salt concentration, then further development would be warranted. In addition, if the process qualification option were investigated, additional work is required to determine time to temperature for the media as well as optimum off-gas flow rates. In addition, design changes for PFP application would be needed to minimize the system size and to ensure ease of maintenance for glovebox operation. Specific items include the following:

- a smaller pore, high-temperature filter to capture the fine salt particles. A high-temperature bag type filter may be optimal for this application.

- reduced in-quench chamber size.

- fewer and lower temperature off-gas heaters. Optimally, insulating the off-gas line may make the heaters unnecessary.

- a quick opening plate to provide access to clean and/or replace the filter.

- a sleeve inside the quench chamber to enable quick removal of the salt that precipitates on the wall. 


\subsection{References}

DOE. 2000. Stabilization, Packaging, and Storage of Plutonium-Bearing Materials, DOE-STD-30132000, U.S. Department of Energy, available online at http://tis.eh.doe.gov/techstds/standard/std3013/std30132000.pdf

Novikov GI and FG Gavryuchenkov. 1964. "Saturated Vapour Pressure of Calcium, Strontium, and Barium Chlorides." Russian Journal of Inorganic Chemistry 9(2):260-261.

Stull DR. 1947. "Vapor Pressure of Pure Substances." Industrial and Engineering Chemistry 39(1):517-540.

Stull DR and H Prophet, eds. 1971. JANAF Thermochemical Tables, 2nd edition, USGPO, Washington, D.C. 


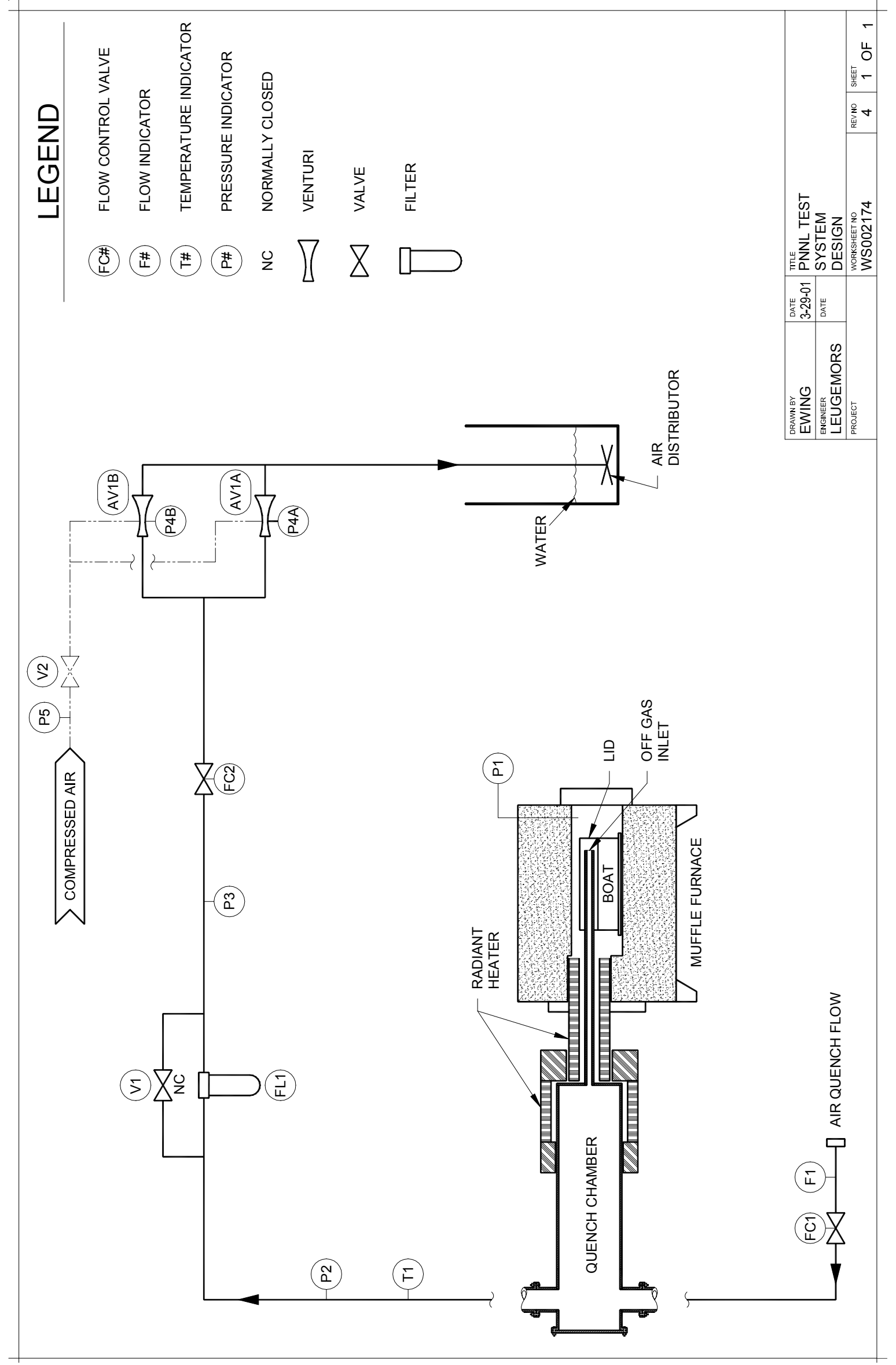

Attachment 1 


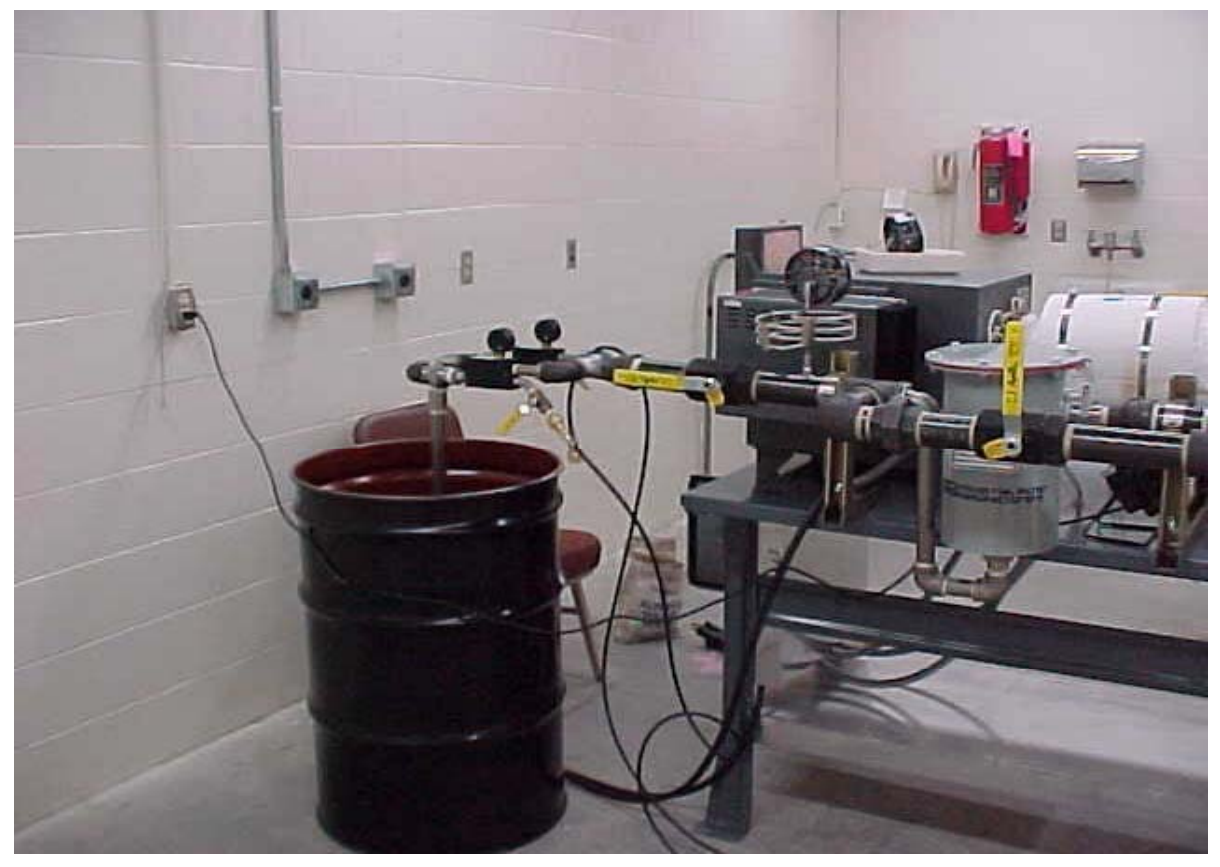

Water-Filled Drum on Left, Air Filter (Gray Cylinder) on Right

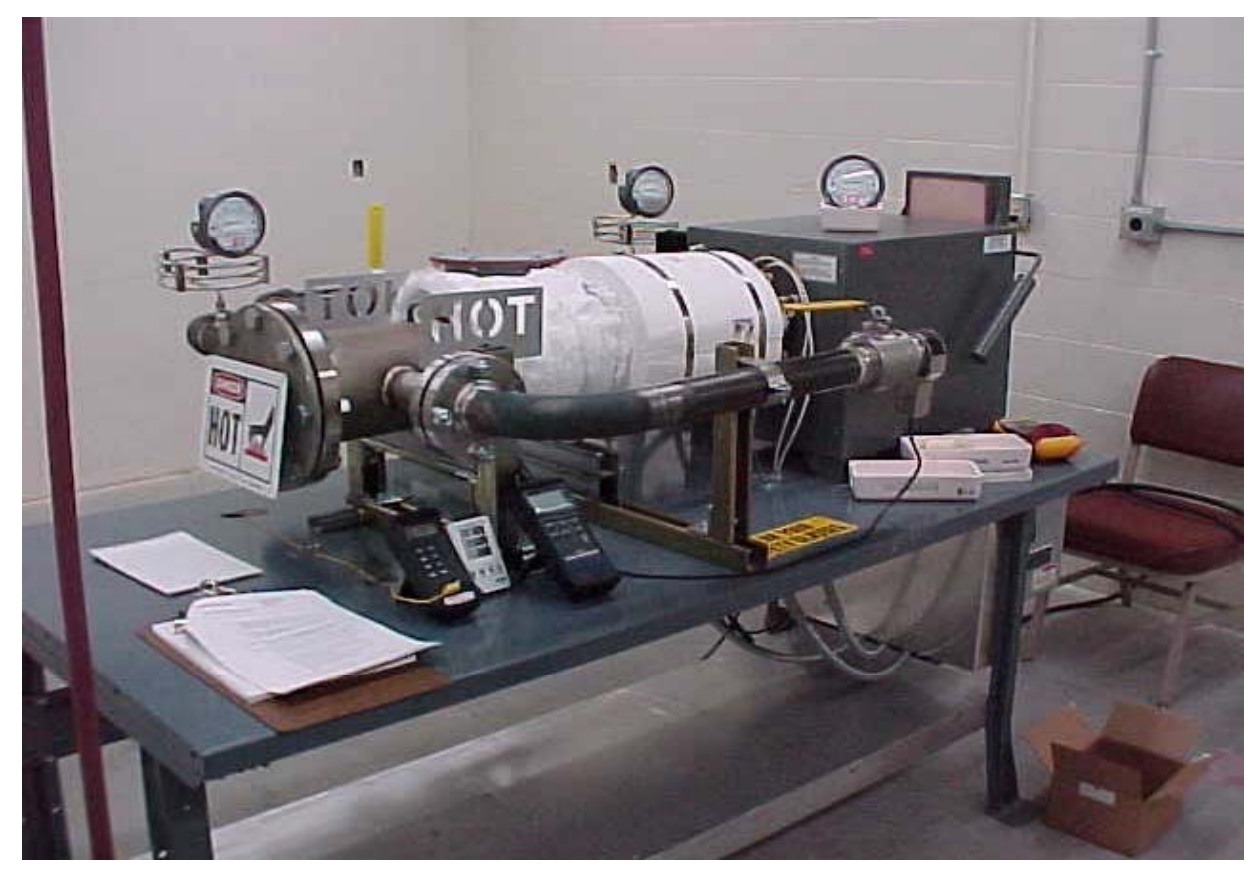

Quench Chamber under White Insulation 


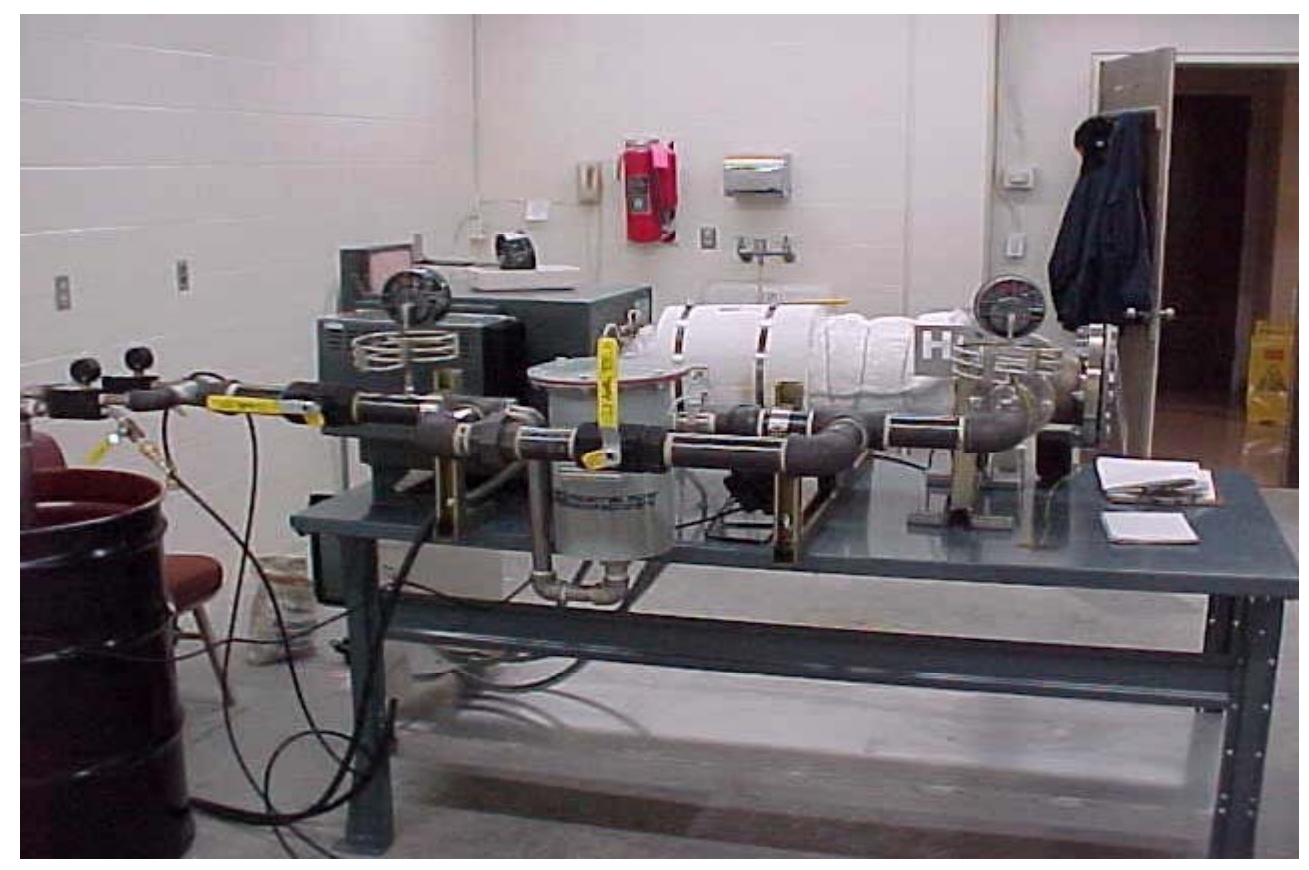

Filter, Quench Chamber, and Muffle Furnace

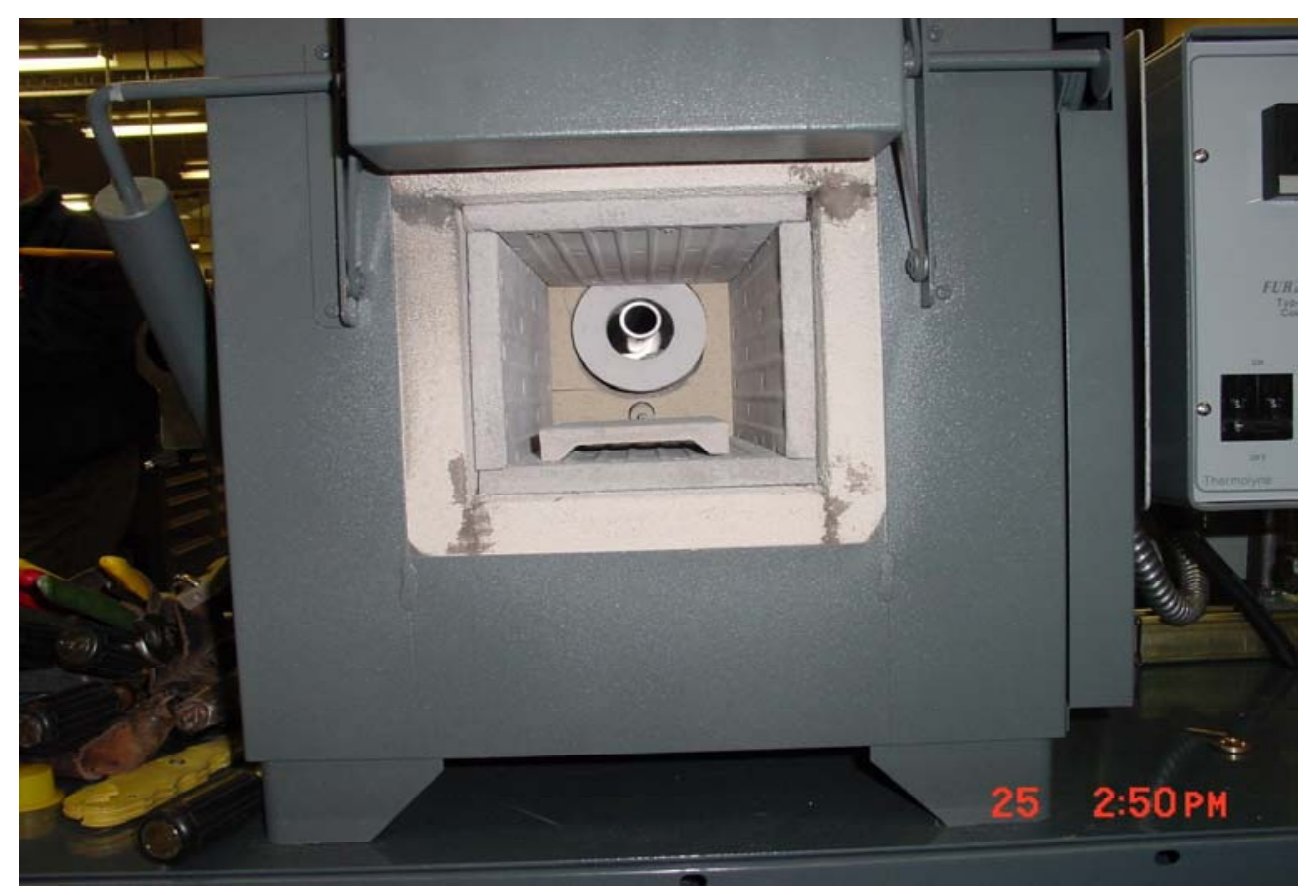

Pre-Run Off-Gas Pipe in the Muffle Furnace which inserts into the Boat/Lid 


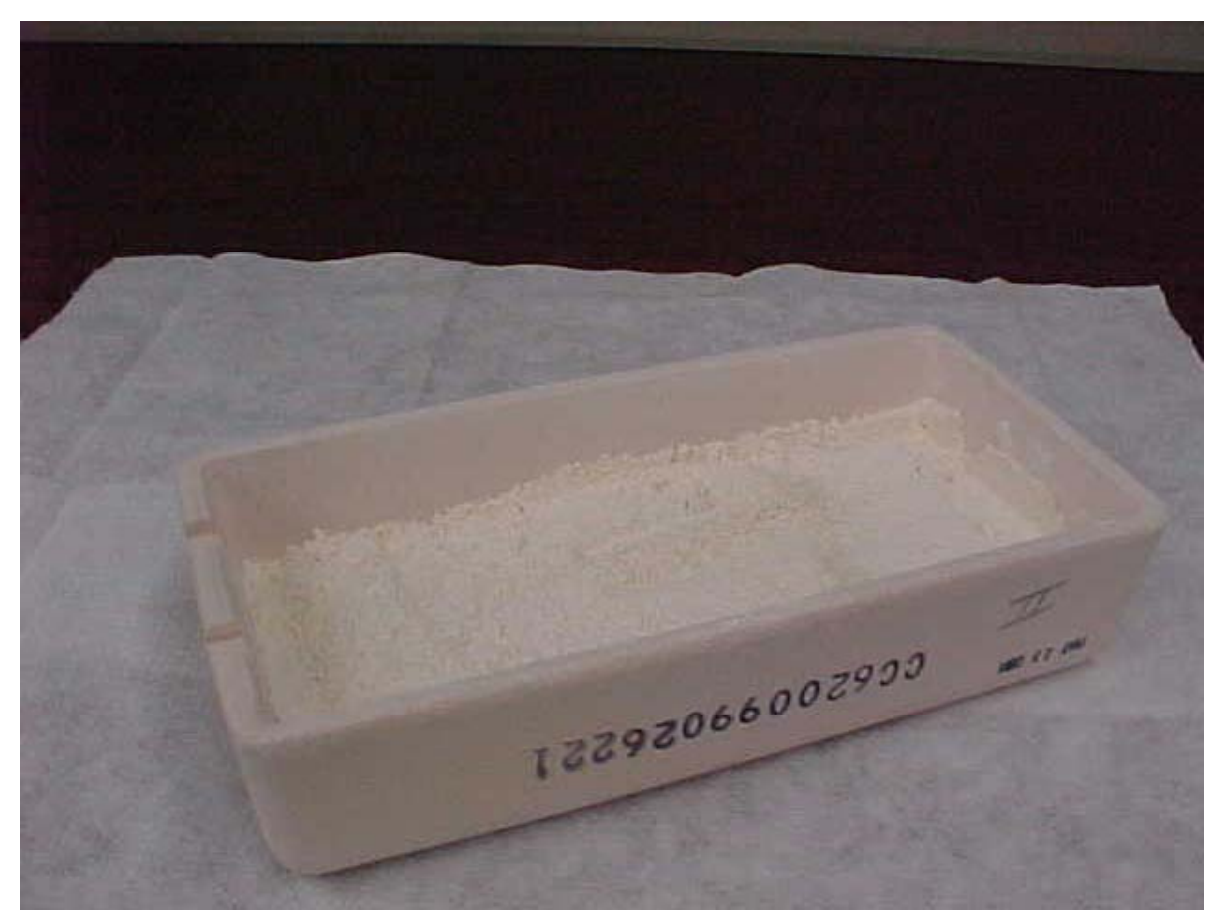

Pre-Run 1 Material in the Ceramic Boat

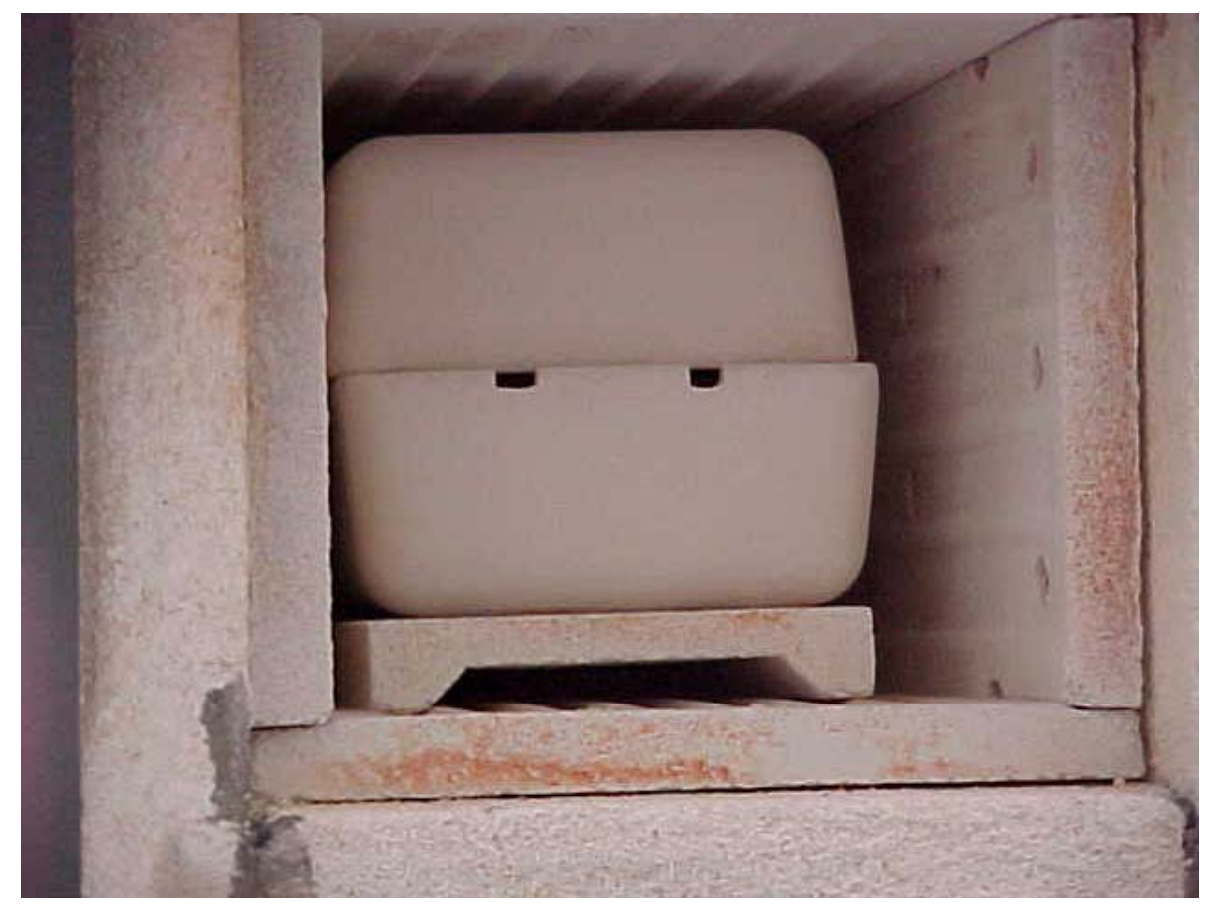

Run 1 Ceramic Boat/Lid 


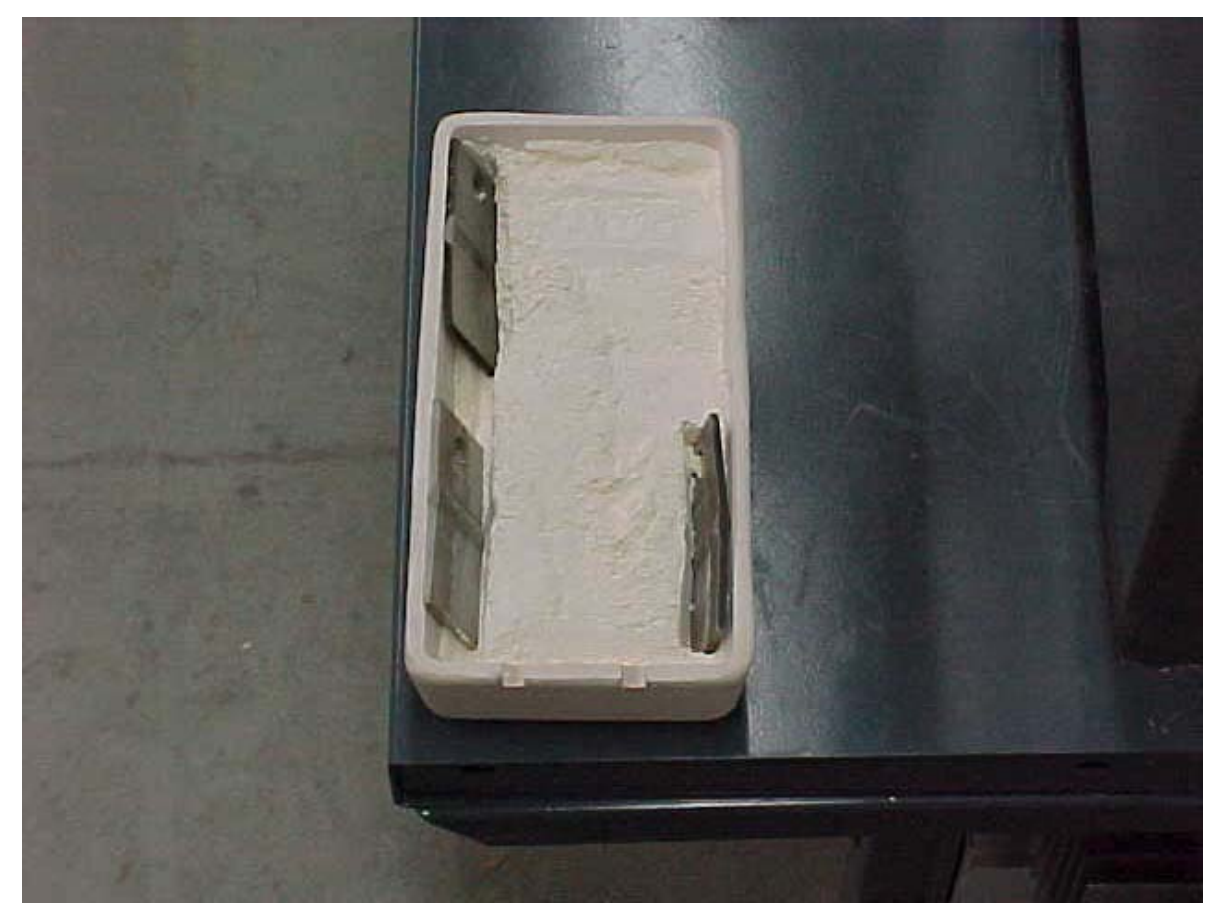

Pre-Run 1 material with metal coupons

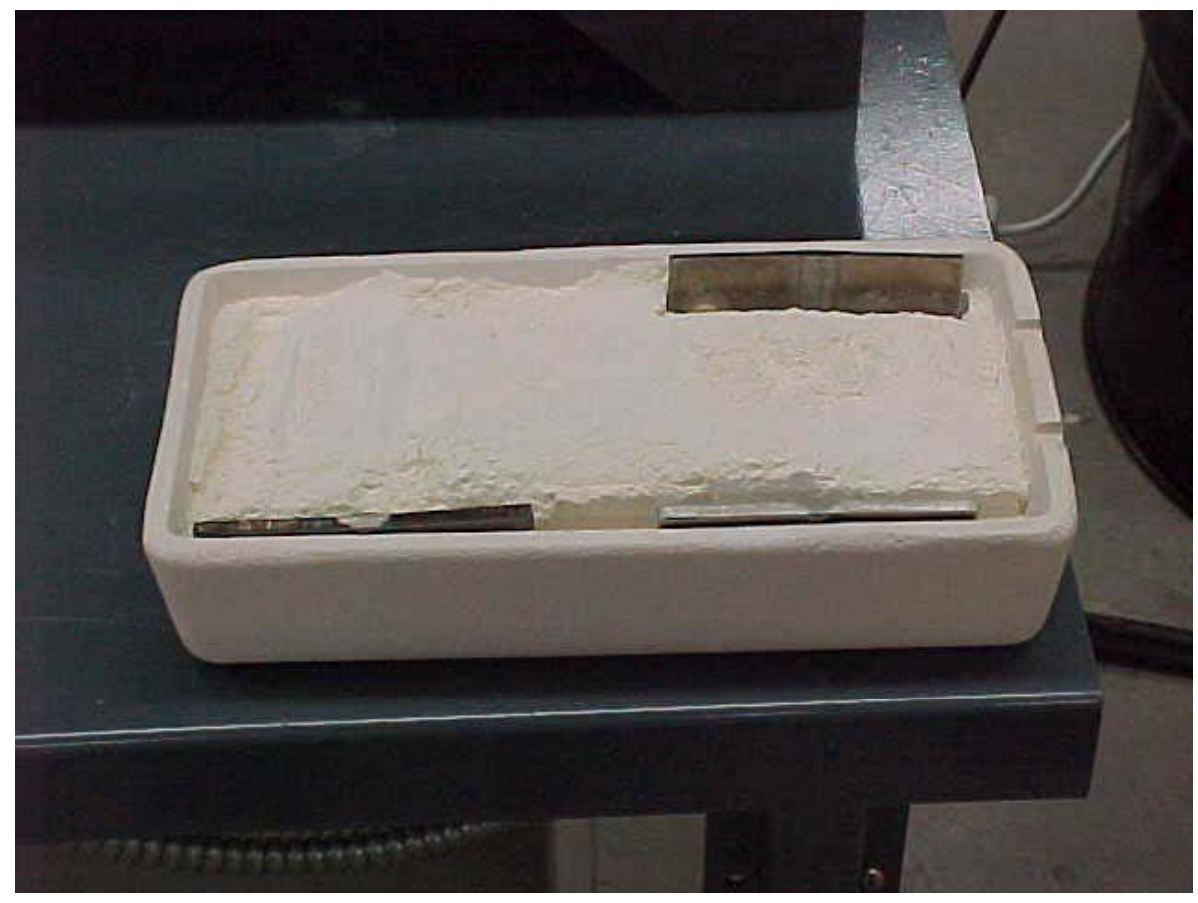

Pre-Run 1 material with metal coupons 


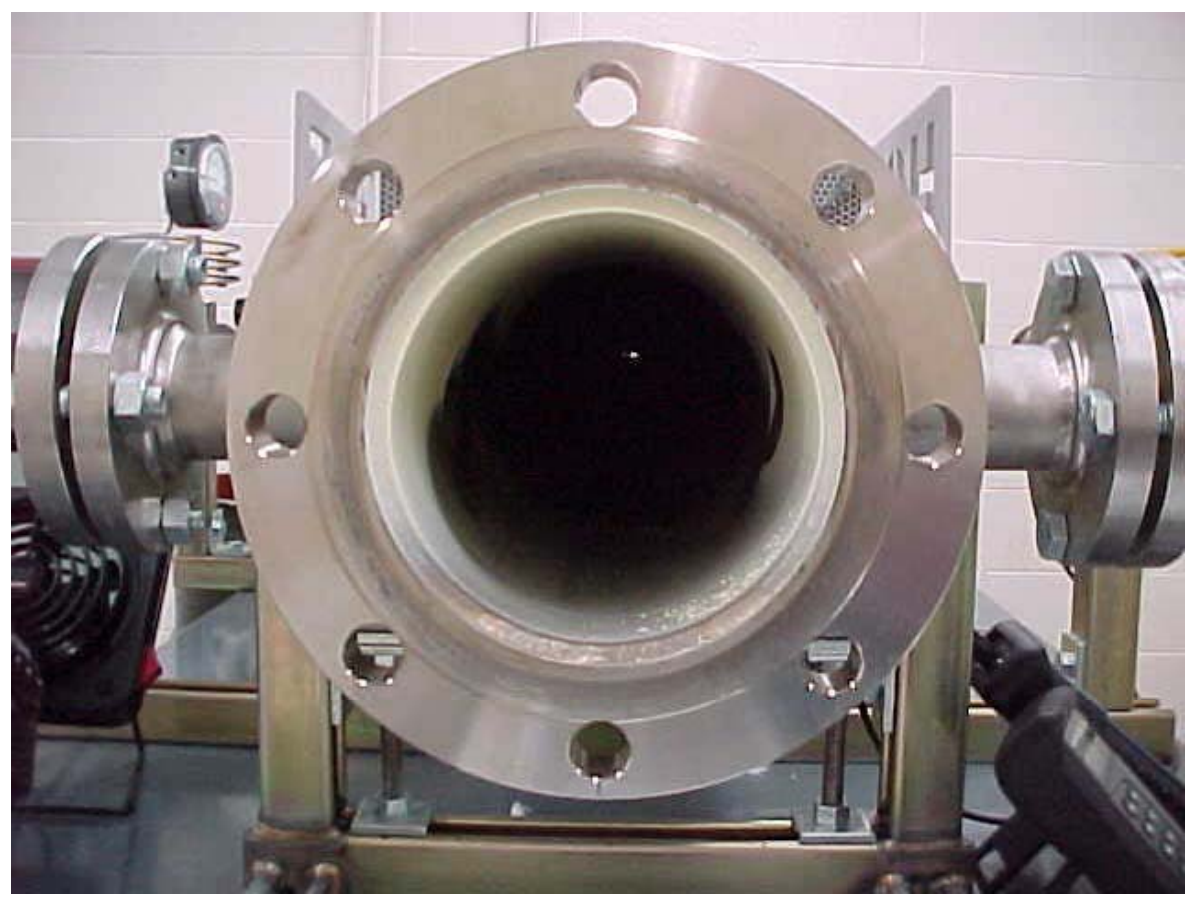

Post Run 1 Quench Chamber

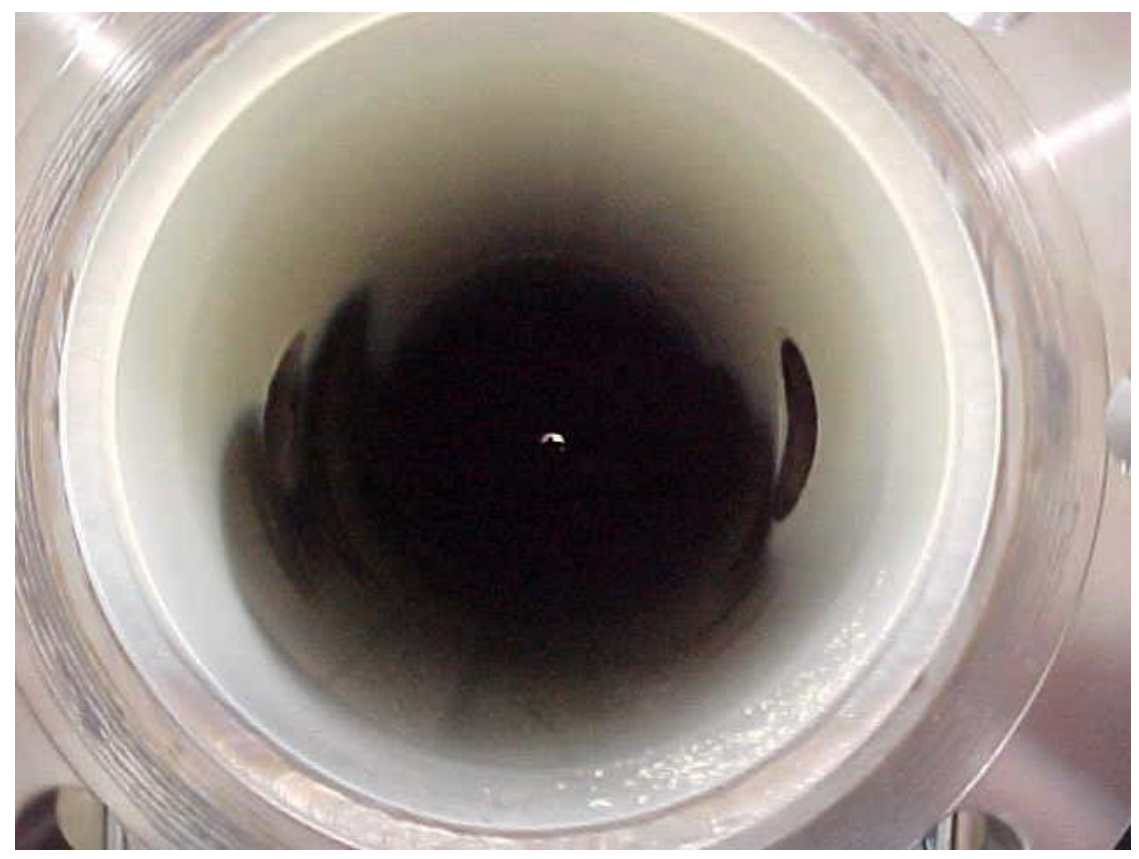

Run 1 Quench Chamber. Note the off-white coating of the The black area had no deposits. 


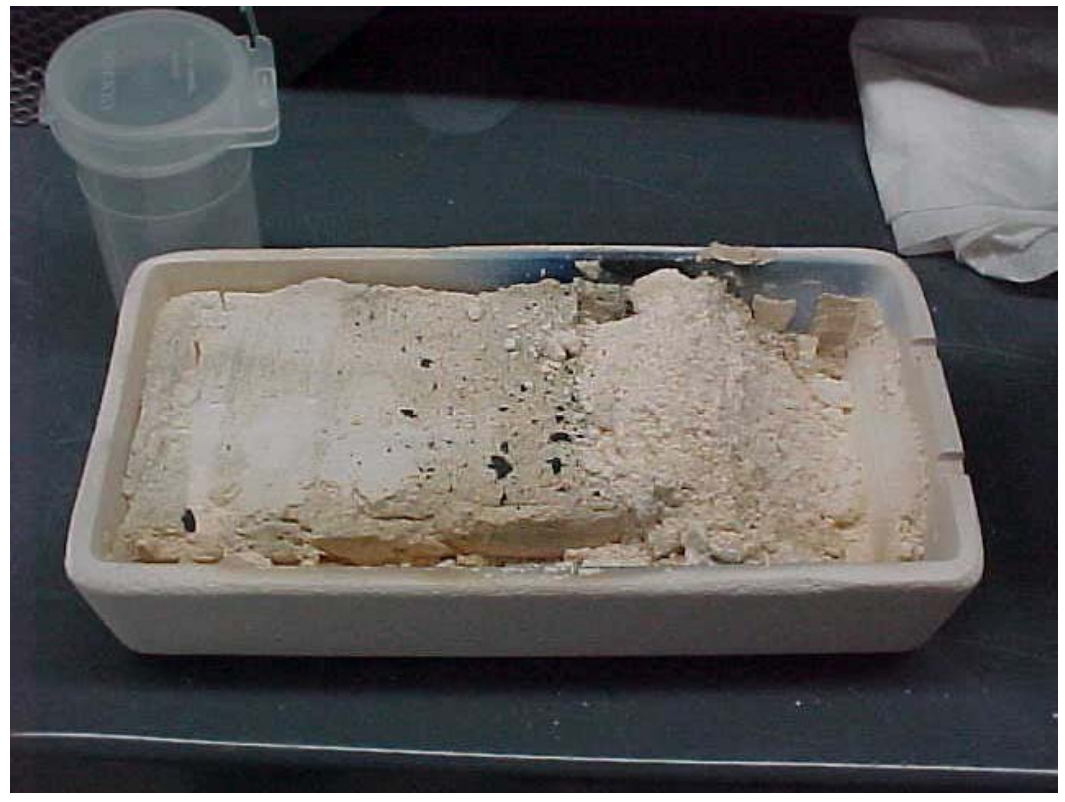

Post Run 1 Material. The area on the right has been disturbed to show the material underneath.

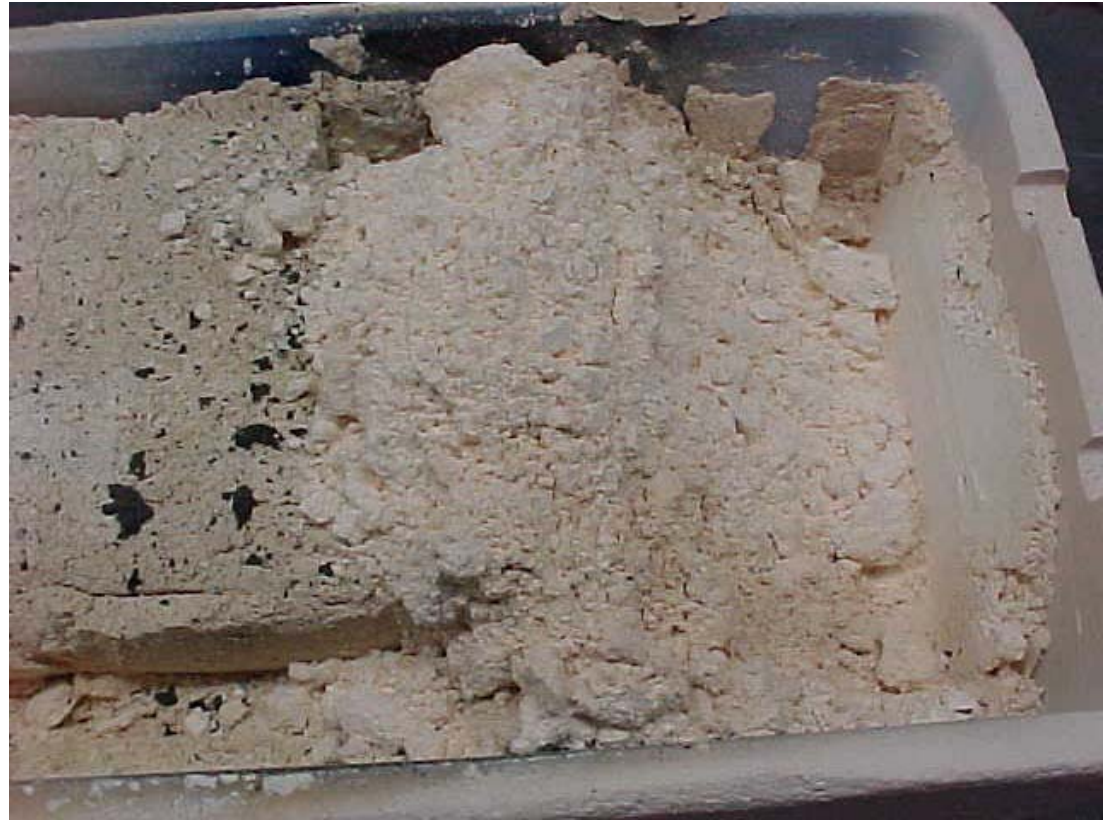

Post Run 1 Material. The area on the right has been disturbed to show the material underneath. 


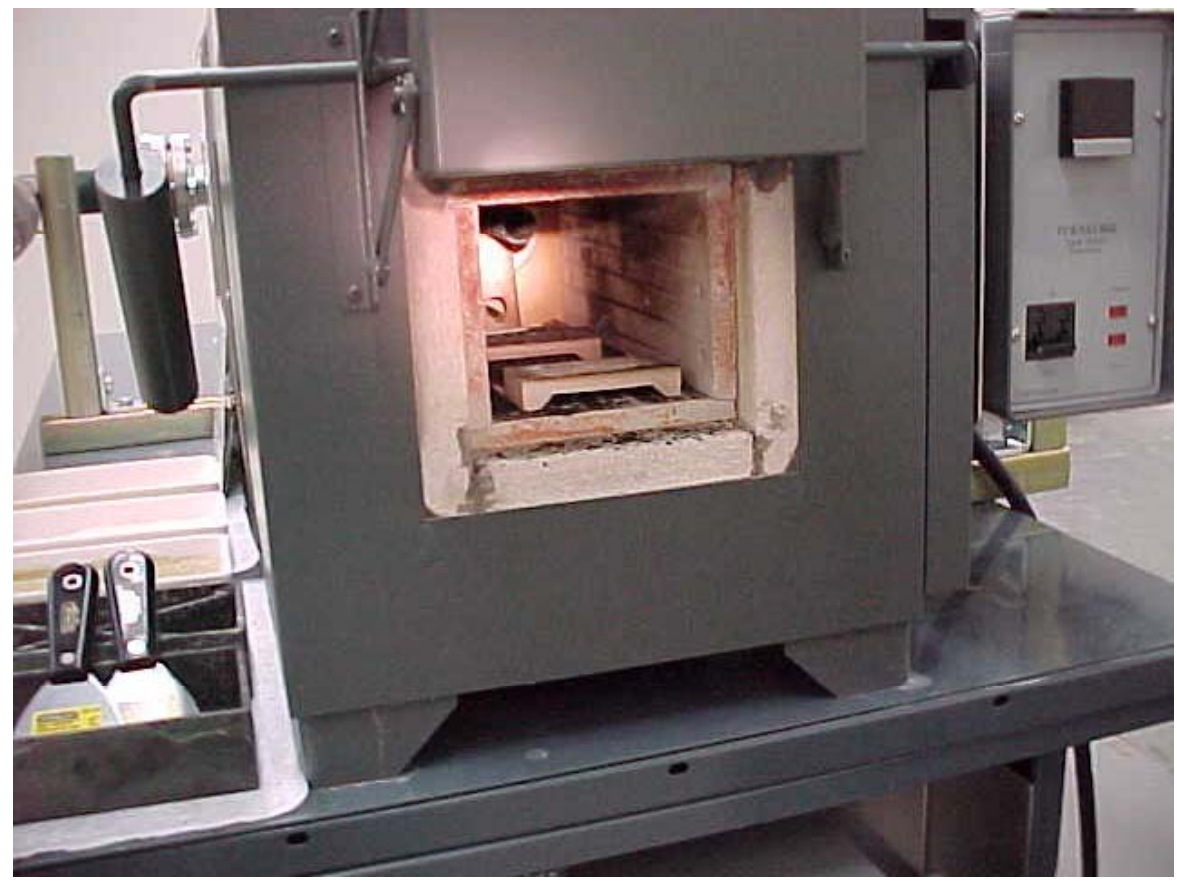

Inside of the Muffle Furnace after Run 2

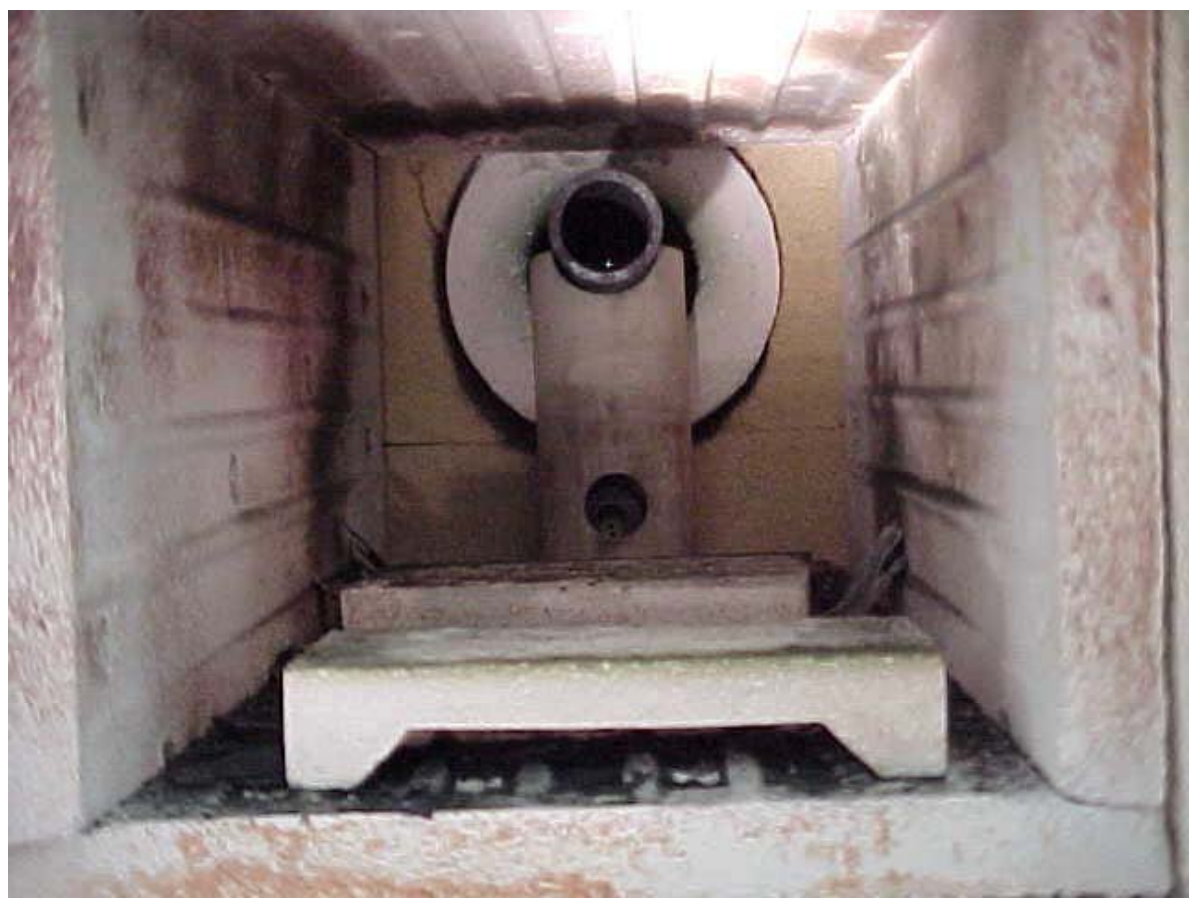

Inside of the Muffle Furnace after Run 2. Note the ceramic piece to support the off-gas pipe. 

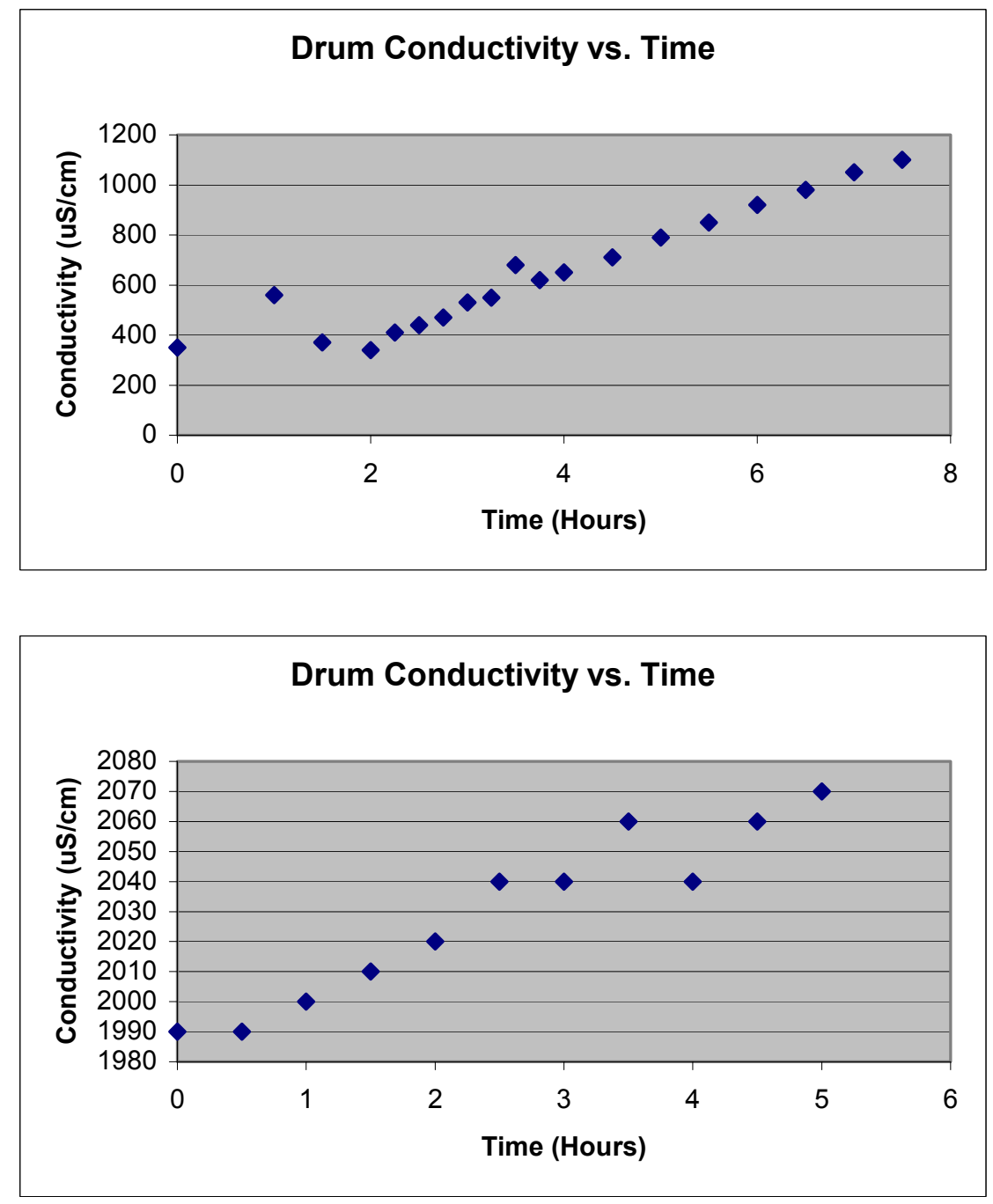

Added baking soda to adjust ph

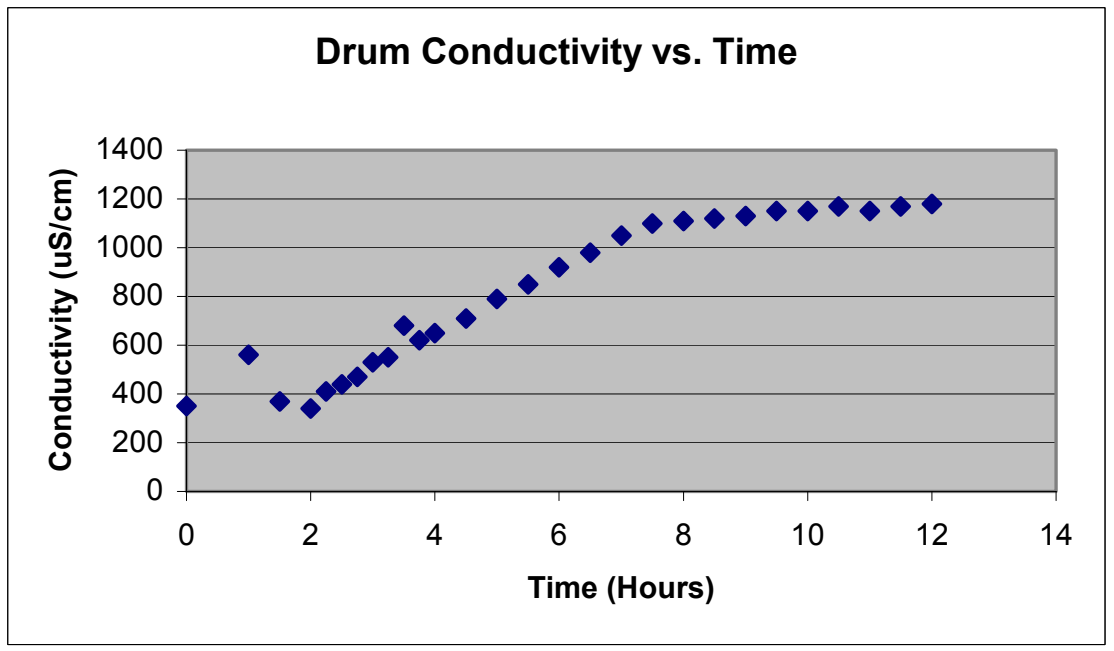

Attachment 3 


\section{Distribution}

No. of

\section{Copies}

\section{ONSITE}

1 DOE

Rick Wible (1) K8-50

\section{Fluor Hanford}

Dwayne Speer (1) T5-50

16 Pacific Northwest National Laboratory

W. F. Bonner (5)

K9-14

R. K. Leugemors (2)

$\mathrm{P} 7-25$

G. Sevigny (2)

K6-28

P. Scott (1)

K9-46

P. MacFarlan (1)

P7-27

S. L. Jones (1)

P7-28

C. Delegard (1)

P7-25

D. Wallace (1)

P7-27

Technical Library (2) 